\title{
Comparisons of measured nitrous acid (HONO) concentrations in a pollution period at urban and suburban Beijing, in autumn of 2014
}

\author{
Shengrui Tong ${ }^{1 *}$, Siqi Hou ${ }^{1}$, Ying Zhang ${ }^{1}$, Biwu $\mathrm{Chu}^{2}$, Yongchun $\mathrm{Liu}^{2}, \mathrm{Hong}^{2}{ }^{2}$, \\ Pusheng Zhao ${ }^{3} \&$ Maofa $\mathrm{Ge}^{1 *}$ \\ ${ }^{1}$ State Key Laboratory for Structural Chemistry of Unstable and Stable Species; Beijing National Laboratory for Molecular Sciences; \\ Institute of Chemistry, Chinese Academy of Sciences, Beijing 100190, China \\ ${ }^{2}$ Research Center for Eco-Environmental Sciences, Chinese Academy of Sciences, Beijing 100085, China \\ ${ }^{3}$ Institute of Urban Meteorology, China Meteorological Administration, Beijing 100089, China
}

Received January 30, 2015; accepted March 20, 2015; published online July 9, 2015

\begin{abstract}
To study the HONO formation mechanisms during a pollution period, a continuous measurement was performed in both urban and suburban aeras of Beijing. During this period, the $\mathrm{PM}_{2.5}$ concentrations increased to 201 and $137 \mu \mathrm{g} / \mathrm{m}^{3}$ in urban and suburban areas, respectively. The concentrations of $\mathrm{HONO}, \mathrm{CO}, \mathrm{SO}_{2}, \mathrm{O}_{3}, \mathrm{NO}, \mathrm{NO}_{2}, \mathrm{NO}_{x}$ were $1.45 \mathrm{ppbv}, 0.61 \mathrm{ppmv}, 8.7 \mathrm{ppbv}$, 4.3 ppbv, 44.4 ppbv, 37.4 ppbv, 79.4 ppbv and 0.72 ppbv, 1.00 ppmv, 1.2 ppbv, 7.9 ppbv, 3.7 ppbv, 8.2 ppbv, 11.9 ppbv, in urban and suburban areas, respectively. To compare possible pathways of HONO formation in both sites, the contributions of direct emissions, heterogeneous formations, and homogeneous productions were studied. $\mathrm{HONO} / \mathrm{NO}_{2}$ ratios in the two sites indicated that heterogeneous reactions of $\mathrm{NO}_{2}$ were more efficient in suburban areas. And in both urban and suburban areas, the increase of $\mathrm{PM}_{2.5}$ concentrations and $R H$ would promote the conversion efficiency in $R H$ that ranged from $0 \%$ to $85 \%$. However, when $R H$ was above $85 \%$, the HONO formation slowed down. Moreover, the study of direct emissions and homogeneous reactions showed that they contributed to a majority of HONO increase in urban areas than the $20 \%$ contributions in suburban areas. It implied that the high $\mathrm{NO}_{x}$ concentrations and $\mathrm{NO}$ concentrations in urban areas or in pollution periods would make direct emissions and homogeneous reactions become dominant in HONO formations.
\end{abstract}

nitrous acid, pollution, urban, suburban, comparison

\section{Introduction}

Nitrous acid (HONO) is one of the important species in photochemical cycles, which could provide hydroxyl radical (OH) $[1,2]$ with contributions up to $30 \%-50 \%$ [3,4]. $\mathrm{OH}$ radical, one of the most improtant oxidant in the atmosphere, can react with organic matters, enhance the capacity of atmospheric oxidation, lead to the formation of secondary pollutants, and accelerate the formation of air pollutions [2].

*Corresponding authors (email: tongsr@iccas.ac.cn; gemaofa@iccas.ac.cn)
Therefore, the study on the HONO formation mechanism will be helpful to understand the complex process during pollution. The genarally accepted sources of HONO were direct emissions, homogeneous reaction of $\mathrm{NO}$ and $\mathrm{OH}$, and heterogeneous reaction of $\mathrm{NO}_{2}$ [4]. $\mathrm{HONO}$ could be emitted directly by combustion processes, with quantities about $0.3 \%-0.8 \%$ of $\mathrm{NO}_{x}\left(\mathrm{NO}+\mathrm{NO}_{2}\right)$ obtained by tunnal studies $[5,6]$. The direct emission sources were seen to be unimportant except in high $\mathrm{NO}_{x}$ regions and traffic hours [7]. The homogeneous reaction of $\mathrm{NO}$ and $\mathrm{OH}$ was also one of the HONO formation sources. It was normally seen as less important due to its low prodution rate [1], but the high 
concentrations of $\mathrm{OH}$ and $\mathrm{NO}$ in pollution strengthened the importance of this reaction source. Laboratory studies indicated that $\mathrm{NO}_{2}$ heterogeneous reactions on humid surfaces can be used to explain parts of the HONO formation [8-11]. The reaction efficiency depended on the surface absorbed water, the surface compositions, and the surface types [11]. However, the mechanism was still in argument due to the differences between laboratory and field measurements [11].

The field observations of HONO were performed in various locations including remote areas, rural areas, suburban and urban areas [3,7,11-25]. Results showed that HONO concentrations were lower in remote places and clean areas. Due to heavy pollution, the HONO concentrations were much higher in mega cities of China. Moreover, the differences of HONO concentrations also lied in urban and suburban areas. For example, it was 1.45 ppbv [18] in urban and $0.89 \mathrm{ppbv}$ [15] in suburban areas of Beijing, $3.50 \mathrm{ppbv}$ [16] in urban and 0.95 ppbv [7] in rural areas of Guangzhou, 1.50 ppbv [14,23] in urban and 1.30 ppbv [20] in non-urban areas in Shanghai. As the indicator of heterogeneous reaction extent, $\mathrm{HONO} / \mathrm{NO}_{2}$ ratios were also different in various places. Normally it was in the range of 0.01 to 0.13 [14,15,17-20], and could reach up to 0.175 [7] and 0.35 [16] at Guangzhou, and 0.42 [25] in Kathmandu with high relative humidity.

The differences in HONO concentrations may be caused due to various reasons in recent China [26-28]. And the measurements in different areas could be helpful to understand the formation mechanism of HONO and the important impacts on HONO in the pollution process. Therefore, in present work, a continuous measurement was performed in the urban and suburban areas of Beijing from October 28 to November 2, with high pollution in both areas. From this measurement, the concentrations of $\mathrm{HONO}$ and $\mathrm{SO}_{2}, \mathrm{O}_{3}$, $\mathrm{CO}, \mathrm{NO}_{x}$ in urban and suburban areas were obtained. Diurnal variations of gaseous species as well as the changing meteorological conditions were analyzed. Moreover, HONO formation sources from direct emissions, homogeneous reactions and heterogeneous reactions in both sites were discussed and different formation mechanisms were obtained.

\section{Materials and methods}

\subsection{Measurement sites}

In this work, as a comparison was performed in urban and suburban areas of Beijing, two sites were chosen for the study.

(1) For the urban area. The HONO measurement was performed at the platform in the third floor in No. 2 building of Institute of Chemistry, Chinese Academy of Sciences (ICCAS, $\left.116^{\circ} 19^{\prime} 21.58^{\prime \prime} \mathrm{E}, 39^{\circ} 59^{\prime} 22.68^{\prime \prime} \mathrm{N}\right)$. The ICCAS site is located at the North Fourth Ring Road of Haidian District, which could be seen as a typical urban area with condensed population and heavy traffic. In addition, the gas phase pollutants of $\mathrm{CO}, \mathrm{SO}_{2}, \mathrm{O}_{3}, \mathrm{NO}, \mathrm{NO}_{2}$ and $\mathrm{NO}_{x}$ were measured by commercial $\mathrm{SO}_{2}$ analyzer (43i, Thermo, USA), $\mathrm{O}_{3}$ analyzer (49i, Thermo, USA), $\mathrm{NO}_{x}$ analyzer (42i, Thermo, USA) and CO analyzer (48i, Thermo, USA) with detection limits of $1 \mathrm{ppbv}, 1 \mathrm{ppbv}, 1 \mathrm{ppbv}$ and $0.05 \mathrm{ppmv}$, respectively. The analyzers were installed at Baolian, 5.5 kilometers southwest from the ICCAS site with similar conditions and little spatial differentiations of $\mathrm{NO}_{2}$ and $\mathrm{NO}_{x}$ concentrations [29]. Meteorological parameters, including wind speed, wind directions, temperature, pressure, relative humidity and $\mathrm{PM}_{2.5}$ concentrations were obtained from http://www.weather.com.cn/weather/101010100.shtml in Baolian station.

(2) For the suburban area. The HONO analyzer and other gas analyzers were settled at the 4th floor of the first classroom building in the Lake yanqi campus of University of Chinese Academy of Sciences (UCAS, $40.4^{\circ} \mathrm{N}, 116.6^{\circ} \mathrm{E}$ ). The UCAS was $50 \mathrm{~km}$ northeast of the city center, and in the west side of the Jingjia highway and was in the northeast of Lake Yanqi within $1 \mathrm{~km}$, which could be an example of suburban area. The gaseous species of $\mathrm{CO}, \mathrm{SO}_{2}$, $\mathrm{O}_{3}, \mathrm{NO}, \mathrm{NO}_{2}$ and $\mathrm{NO}_{x}$ were measured by analyzers as used in the urban site. And meterological parameters were also obtained from http://www.weather.com.cn/weather/101010 100.shtml in Huairou station.

\subsection{Measurement instruments of HONO}

During the experiment, the HONO concentrations were measured by a home-made HONO analyzer in each site. The mechanism of the analyzer was based on long pathlength absorbance spectroscopy [30,31]. HONO was absorbed by a solution containing $0.06 \mathrm{~mol} / \mathrm{L}$ sulfanilamide in $1 \mathrm{~mol} / \mathrm{L} \mathrm{HCl}$ [32], and then formed an azo dye by reacting with a dye solution $(0.8 \mathrm{mmol} / \mathrm{L} N$-(1-naphthyl) ethylenediaminedihydrochloride) [31]. The azo dye was pumped into $250 \mathrm{~cm}$ Teflon absorption cells (Liquid Core Waveguide, LCW) [30] and detected by a mini-spectrometer with a diode array detector (Ocean Optics, SD2000) [32]. The gas collecting device was designed to be of two channels, which could get a real HONO concentration by subtracting the interferences [30]. The sampled gas flow rate was $1 \mathrm{~L} / \mathrm{min}$ with the solutions liquid flow rate of $0.5 \mathrm{~mL} / \mathrm{min}$. The detection limit of the HONO analyzer was $9 \mathrm{pptv}$ with a response time (the time of the instrument rising to $90 \%$ of the full signal) of $5 \mathrm{~min}$. Moreover, an inter-comparison of the two home-made HONO analyzers used in each site was performed. And the differences of measured concentrations lied within 0.008 , which indicated the concentrations measured by the two HONO analyzers in the two sites were reliable and comparable. 


\section{Results and discussion}

\subsection{Time series of meteorological parameters and measured gases species}

The measured meteorological parameters, i.e., air temperature $(T)$, relative humidity $(R H)$, wind speed $(W S)$ and direction $(W D)$ as well as the $\mathrm{PM}_{2.5}$ concentrations were illustrated in Figure 1. According to the National Ambient Air Quality Standard (ambient air quality standards which is to be implemented in 2016: GB3095-2012), two successive days with the daily mass concentration of $\mathrm{PM}_{2.5}$ exceeding $75 \mu \mathrm{g} / \mathrm{m}^{3}$ were defined as an air pollution episode. Therefore, a heavy pollution occurred from the midnight of Oct. 29 to the early morning in Nov. 1 at the urban area of Beijing, with average $\mathrm{PM}_{2.5}$ mass concentration of $150 \mu \mathrm{g} / \mathrm{m}^{3}$. Whereas, the pollution period in suburban areas was from 9:00 LTS in Oct. 29 to the midnight of Oct. 31, with the average $\mathrm{PM}_{2.5}$ concentration of $103 \mu \mathrm{g} / \mathrm{m}^{3}$.

Moreover, during the pollution period, the variations of temperatures, wind speeds and the relative humidities were similar between the two sites. The meterological parameters are listed in Table 1. In urban and surburban sites, the temperature was from 4.5 to $16.4{ }^{\circ} \mathrm{C}$ and from 1.7 to $16.7{ }^{\circ} \mathrm{C}$, the relative humidity range was from $47 \%$ to $100 \%$ and from $34 \%$ to $100 \%$, the wind speed was with a mean value of 0.56 and $0.96 \mathrm{~m} / \mathrm{s}$, respectively. However, the $\mathrm{PM}_{2.5}$ concentrations in the two sites were different: (1) the max hourly averaged $\mathrm{PM}_{2.5}$ concentrations was 201 and 137 $\mu \mathrm{g} / \mathrm{m}^{3}$, in urban and suburban areas, respectively; (2) the growth rate of $\mathrm{PM}_{2.5}$ concentations were much higher in urban areas; (3) 4 significant peaks were observed in urban areas, while only 3 peaks in the suburban areas. After the pollution period, the meterological conditions changed in both sites from Nov. 1 with stronger wind speeds and lower relative humidities.

Figure 2 shows the time series of the concentrations measured in each site during the observation period. The average concentrations of the measured gaseous pollutants in both sites are listed in Table 2. HONO was from 0.54 to $2.77 \mathrm{ppbv}$ with the average of $1.45 \mathrm{ppbv}$ in urban area, and from 0.18 to $1.23 \mathrm{ppbv}$ with the average of $0.74 \mathrm{ppbv}$ in suburban area. In the studies of Spataro et al. [18], HONO concentration was $1.06 \mathrm{ppbv}$ on average, with mean $\mathrm{NO}_{2}$ concentration of $38.8 \mathrm{ppbv}$ in urban Beijing. Hendrick et al. [15] showed a HONO concentration of 2 ppbv in urban area of Beijing with $1.25 \mathrm{ppbv}$ at the same time in Xianghe. Moreover, during the period from Oct. 28 to Oct. 31, the max HONO concentrations had a decreasing trend in urban areas, while increasing in the surburban areas. The average concentrations of $\mathrm{NO}, \mathrm{NO}_{2}, \mathrm{NO}_{x}$ and $\mathrm{SO}_{2}$ in urban areas were much higher than that in suburban areas except the concentrations of $\mathrm{CO}$ and $\mathrm{O}_{3}$. It was interesting that the concentrations of $\mathrm{CO}, \mathrm{NO}$ and $\mathrm{NO}_{x}$ in urban areas showed similar variations with peaks at night and minimum in the afternoon, while these correlations were not significant for the suburban areas. During the pollution period, the hourly averaged concentrations of $\mathrm{NO}, \mathrm{NO}_{2}, \mathrm{NO}_{x}$, and $\mathrm{HONO}$ in urban areas were equally $12.7,4.5,6.6$, and 2.0 times higher, and $\mathrm{SO}_{2}, \mathrm{CO}, \mathrm{O}_{3}$ were 7.9, 1.7 and 1.8 times lower than in suburban areas.

Furthermore, these species had clear diurnal variations in

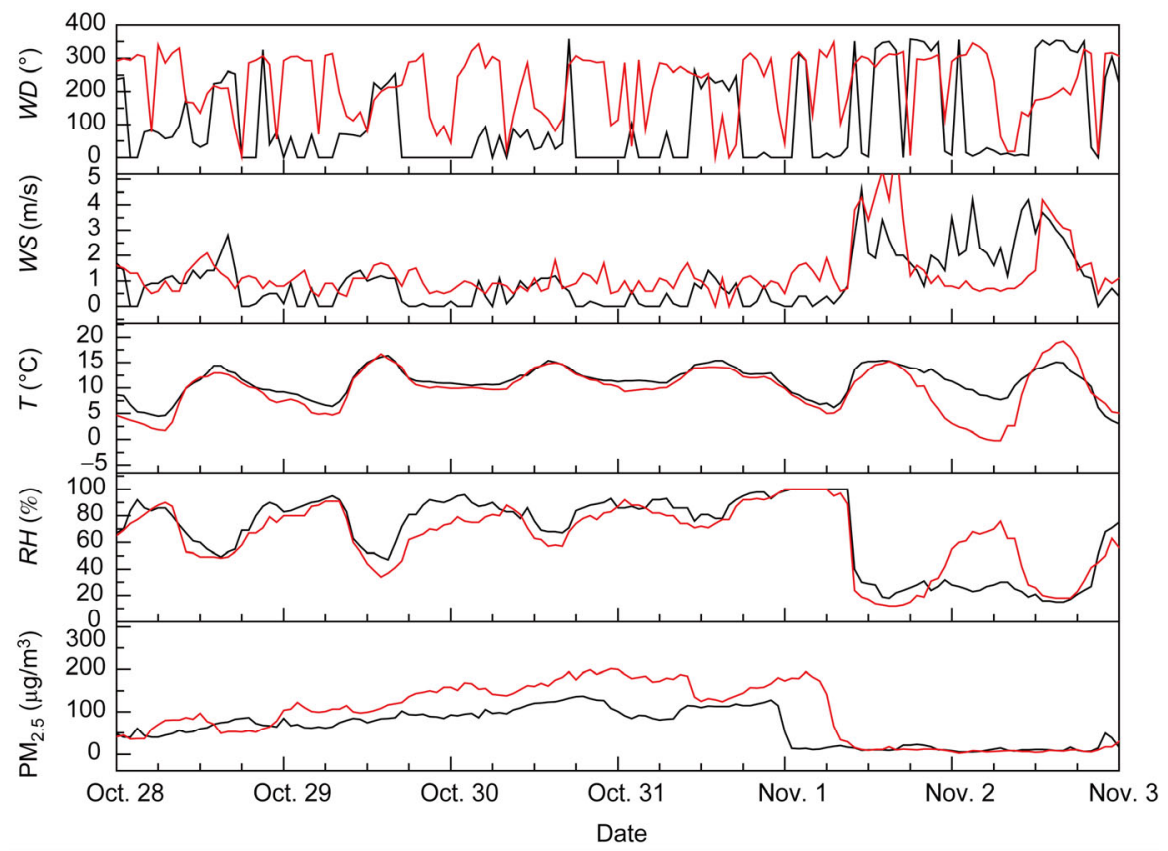

Figure 1 Time series of hourly-averaged air temperature $(T)$, relative humidity $(R H)$, wind speed (WS) and direction (WD) and PM ${ }_{2.5}$ concentrations during Oct. 28 to Nov. 2, 2014. Red lines represent the results from urban station, while the black ones represent the results from suburban station. 
Table 1 Summary of the meterological parameters and $\mathrm{PM}_{2.5}$ concentrations in urban and suburban sites

\begin{tabular}{cccccc}
\hline & $W D$ & $W S(\mathrm{~m} / \mathrm{s})$ & $T\left({ }^{\circ} \mathrm{C}\right)$ & $R H(\%)$ & $\begin{array}{c}\mathrm{PM}_{2.5} \\
\left(\mu \mathrm{g} / \mathrm{m}^{3}\right)\end{array}$ \\
\hline Urban $^{\text {a) }}$ & North & $0-2.8$ & $4.5-16.4$ & $47-100$ & $36-201$ \\
Suburban $^{\text {a) }}$ & Northwest & $0-2.1$ & $1.7-16.7$ & $34-100$ & $40-137$
\end{tabular}

a) Data obtained from http://www.weather.com.cn/weather/101010 100.shtml.
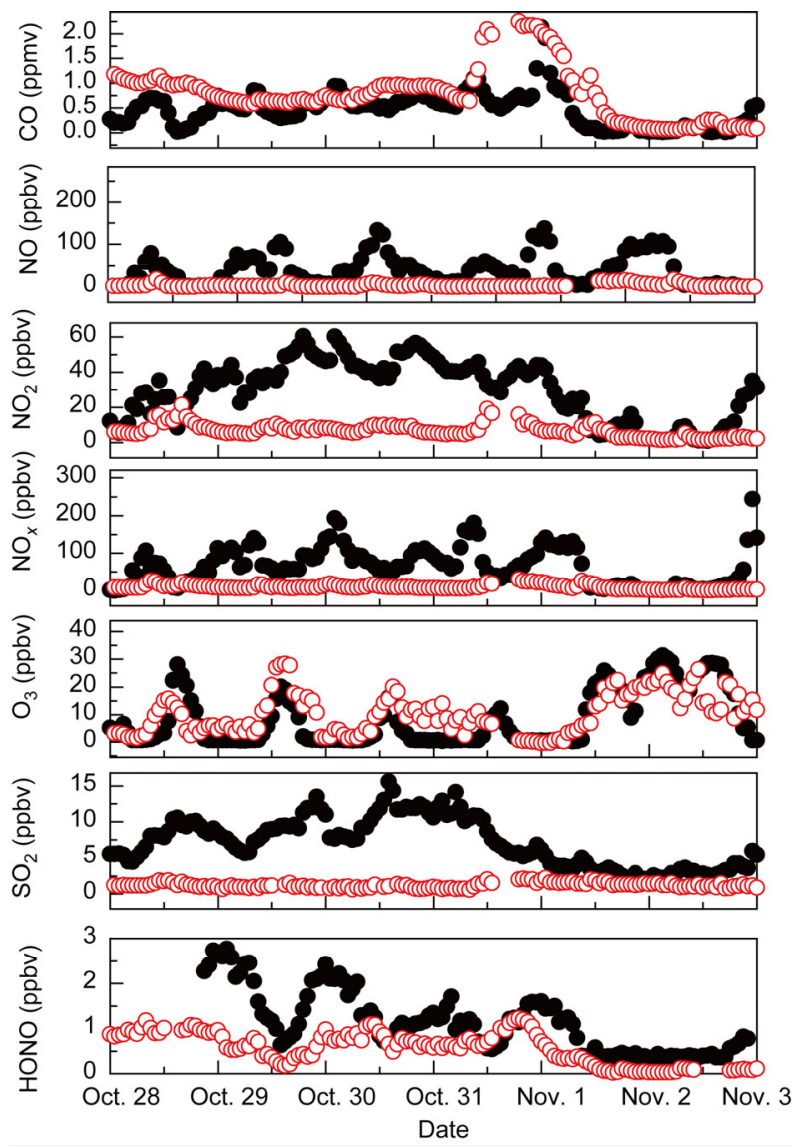

Figure 2 Temporal variations of $\mathrm{CO}, \mathrm{SO}_{2}, \mathrm{O}_{3}, \mathrm{NO}, \mathrm{NO}_{2}, \mathrm{NO}_{x}$, and HONO in 1-h average during Oct. 28 to Nov. 2, 2014. The solid points represent the results from urban areas, while the hollow ones represent the results from suburban areas.

Table 2 Daytime and nighttime average concentrations of the measured chemical species in urban and suburban areas

\begin{tabular}{cccc}
\hline Species & $\begin{array}{c}\text { Daytime } \\
\text { suburban/urban }\end{array}$ & $\begin{array}{c}\text { Nighttime } \\
\text { suburban/urban }\end{array}$ & $\begin{array}{c}\text { Total (ppbv) } \\
\text { suburban/urban }\end{array}$ \\
\hline $\mathrm{HONO}$ & $0.73 / 0.93$ & $0.72 / 1.75$ & $0.74 / 1.45$ \\
$\mathrm{SO}_{2}$ & $1.3 / 9.6$ & $1.1 / 8.1$ & $1.2 / 8.7$ \\
$\mathrm{CO}$ & $1.00 / 0.48$ & $1.04 / 0.68$ & $1.0 / 0.61$ \\
$\mathrm{O}_{3}$ & $11.5 / 10.3$ & $4.9 / 1.3$ & $7.9 / 4.3$ \\
$\mathrm{NO}$ & $1.9 / 19.1$ & $4.4 / 56.9$ & $3.8 / 44.4$ \\
$\mathrm{NO}_{2}$ & $11.3 / 35.3$ & $6.7 / 37.6$ & $8.4 / 37.4$ \\
$\mathrm{NO}_{x}$ & $13.2 / 53.4$ & $11.0 / 8.6$ & $11.9 / 79.4$ \\
\hline
\end{tabular}

a) Daytime: 09:00-17:00 LST; b) nighttime: 19:00-7:00 LST. both urban and suburban areas (Figure 3). The variations of HONO concentrations have differences between urban and suburban areas. For the urban area, HONO kept decreasing by photolysis after 7:00 AM and reached minimum at around 15:00 PM. Then it grew slowly during the rest of the day, and maintained high concentrations through all night until next morning. However, in the suburban area, HONO concentration changed more gently in both daytime and nighttime except two peaks around 9:00 AM and 19:00 PM, respectively. It may be associated with the local traffic according to both $\mathrm{NO}_{2}$ and $\mathrm{NO}_{x}$ peaks at the same time. The $\mathrm{CO}$ had clear diurnal variations with higher values at night and lower values at daytime as similar to the variations of $\mathrm{NO}_{x}$ and $\mathrm{NO}$ in urban areas. All of them showed significant peaks in the morning, and decreased during the daytime until 15:00 LST, then increased during the night with maximums at midnight. In the suburban area, unlike the slight changing of $\mathrm{CO}$, the $\mathrm{NO}_{x}$ and $\mathrm{NO}$ showed typical peaks at around 9:30 LST in the morning and 1:00 LST at midnight. The $\mathrm{SO}_{2}$ decreased from the midnight and increased at 6:00 until 14:00 LST in urban area, then had little changes the rest of the day. While in the suburban area, the increasing time of $\mathrm{SO}_{2}$ was delayed to 8:00, and decreased from 16:00. In the urban area, the $\mathrm{NO}_{2}$ concentrations were higher at



Figure 3 Average diurnal patterns of $\mathrm{CO}, \mathrm{NO}, \mathrm{NO}_{2}, \mathrm{NO}_{x}, \mathrm{O}_{3}, \mathrm{SO}_{2}$ and HONO during the measurement period. The data was calculated by averaging the concentrations of Oct. 28-Oct. 31, 2014. The error bars represent the standard deviation within the measurement period. The solid points represent the results from urban site, while the hollow ones represent the results from suburban site. 
night and lower at day, while the variations in suburban area were opposite to that. $\mathrm{NO}_{2}$ increased at 8:00 in the morning and kept high values until 19:00 LST. The higher $\mathrm{NO}_{2}$ was caused by the oxidation of the emitted NO around 10:00 LST. Although the max values of $\mathrm{O}_{3}$ in the two sites were similar, the increasing time was delayed from 8:00 to 11:00 LST in urban areas.

The similar variations of gases pollutants may indicate similar sources of them $[3,18]$. Therefore, the sources of $\mathrm{CO}$, $\mathrm{NO}$, and $\mathrm{NO}_{x}$ were similar in urban areas, while they were more complicated in suburbans. Normally, $\mathrm{CO}$ and $\mathrm{NO}_{x}$ were mainly from combustion processes including the burning of fossil fuel and biomass, as well as vehicle emissions [26-28]. The sources of $\mathrm{SO}_{2}$ would mainly come from the burning of fossil fuel and biomass, which often happened in the suburban [26]. Therefore, the good correlations of $\mathrm{CO}$ and $\mathrm{NO}_{x}$ in urban areas may be caused by the life sources and the mobile sources [28], like vehicle emissions; and the weak correlations of $\mathrm{CO}, \mathrm{NO}_{x}$ and $\mathrm{SO}_{2}$ in suburban areas may be caused by a combination of fossil fuel burning, biomass burning, vehicle emissions and other combustion processes.

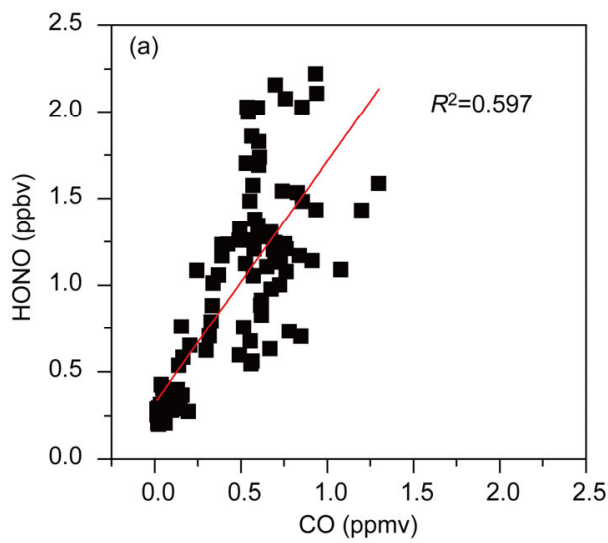

\subsection{The impact factors on HONO formation}

\subsubsection{The direct emissions}

For the evaluation of direct $\mathrm{HONO}$ formation sources, relationships between $\mathrm{HONO}$ with $\mathrm{CO}, \mathrm{NO}_{x}$ and $\mathrm{SO}_{2}$ were studied (Figures 4-6). The correlations of HONO with $\mathrm{CO}$, $\mathrm{NO}_{x}$, and $\mathrm{SO}_{2}$ were 0.597 and $0.665,0.679$ and $0.439,0.380$ and 0.022 for the urban area and the suburban area, respectively. Therefore, the HONO sources in urban areas were partly connected with the sources of $\mathrm{CO}, \mathrm{NO}_{x}$ and $\mathrm{SO}_{2}$ $[3,18]$. While in the suburban areas, the HONO sources were connected with the sources of $\mathrm{CO}$ and $\mathrm{NO}_{x}$. Although both of the measurement sites were closed to a traffic source, the traffic flows and types were different. The traffic close to the urban site was much higher with mainly passenger cars, however, the traffic at the suburban site was more complicated, where the train station, small factories and farmland were not far away. Moreover, the existence of Lake Yanqi may also have effects on the surrounding conditions.

The HONO/NO $\mathrm{Natio}_{x}$ was used to evaluate the amounts by direct emissions in the atmosphere [3]. The HONO/ $\mathrm{NO}_{x}$

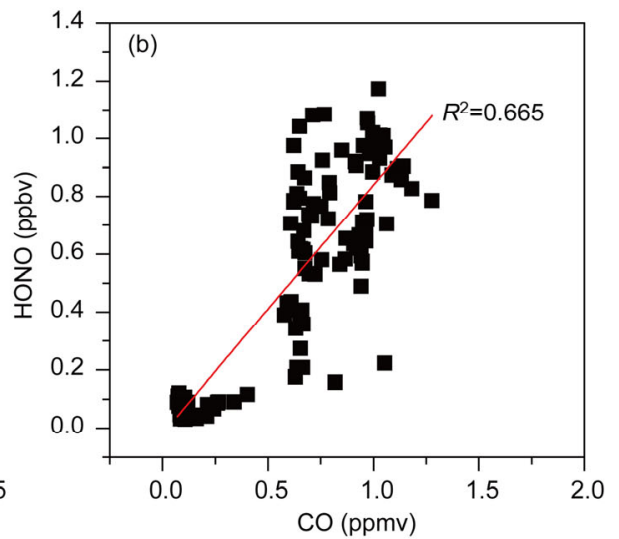

Figure 4 The correlations between HONO and CO in urban site (a) and suburban site (b), by using the data from Oct. 28 to Oct. 31, 2014.
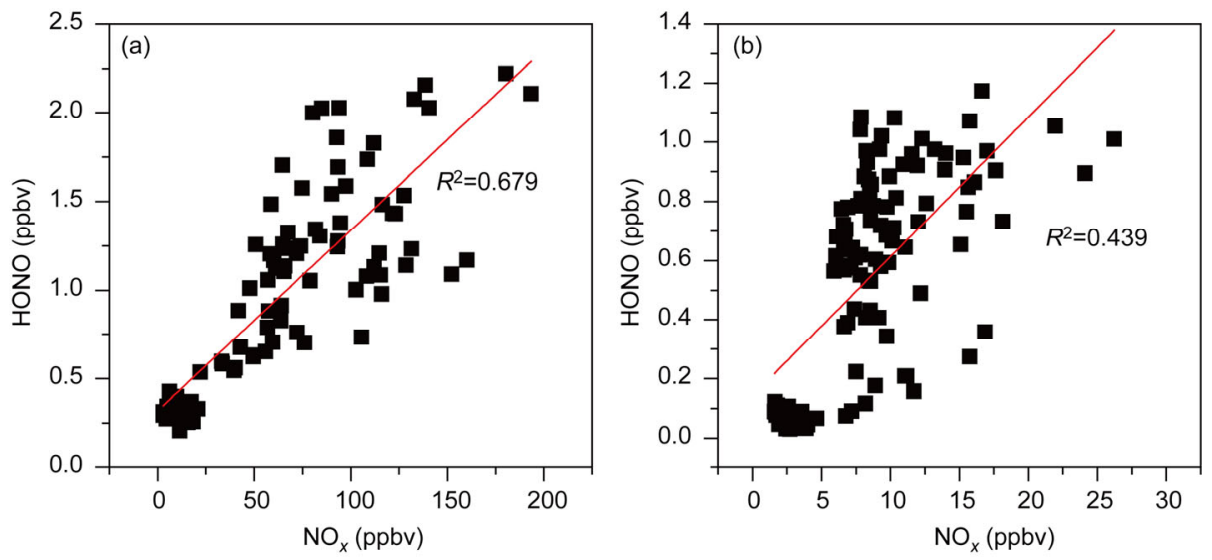

Figure 5 The correlations between $\mathrm{HONO}$ and $\mathrm{NO}_{x}$ in urban site (a) and suburban site (b), by using the data from Oct. 28 to Oct. $31,2014$. 

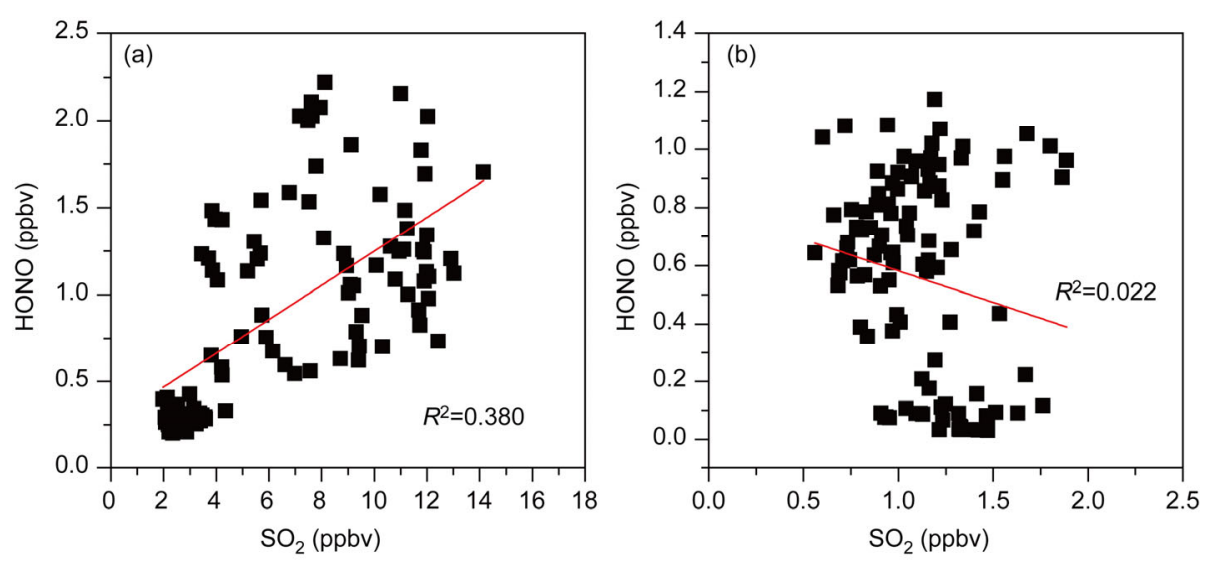

Figure 6 The correlations between $\mathrm{HONO}$ and $\mathrm{SO}_{2}$ in urban site (a) and suburban site (b), by using the data from Oct. 28 to Oct. 31, 2014.

ratio of 0.0065 as the direct emission factor supported by Kurtenbach et al. [5] was widely accepted in most recent studies [7,18-24]. In this work, the average $\mathrm{HONO} / \mathrm{NO}_{x}$ ratios during the pollution period obtained in urban and suburban areas were 0.017 and 0.070 , respectively. The $\mathrm{HONO} / \mathrm{NO}_{x}$ ratios showed two peaks in consistance with the morning and evening traffic hours in urban areas, which were caused by the emissions of vehicle exhausts. However, all these measured $\mathrm{HONO} / \mathrm{NO}_{x}$ ratios were much higher than the direct emission factor of 0.0065 . It is implied that, the HONO in the ambient atmosphere not only comes from direct emissions, but also comes from secondly formation and other pathways. Therefore, 0.0065 was used to calculate the direct emissions concentrations of $\mathrm{HONO}\left(\mathrm{HONO}_{\text {emission }}\right)$ by the formula: $\left[\mathrm{HONO}_{\text {emission }}\right]=\left[\mathrm{NO}_{x}\right] \times 0.0065 \quad[16,18]$. Where, $\left[\mathrm{HONO}_{\text {emission }}\right]$ and $\left[\mathrm{NO}_{x}\right]$ represented HONO concentrations by direct emissions and the concentrations of $\mathrm{NO}_{x}$, respectively. The calculated $\mathrm{HONO}_{\text {emissions }}$ was with contributions of $39.6 \%$ and $8.5 \%$ on average, in urban and suburban areas, respectively. In previous studies, the contributions of $\mathrm{HONO}_{\text {emission }}$ could be $49.7 \%$ with $266 \mathrm{ppbv}$ $\mathrm{NO}_{x}$ in urban Beijing [18]. The comparison of $\mathrm{HONO}_{\text {emissions }}$ in both sites in this measurement indicated that direct emissions are more important in urban areas.

\subsubsection{The nocturnal heterogeneous reaction of $\mathrm{NO}_{2}$}

It was well-accepted that HONO could be formed on the wet surface by heterogeneous conversion of $\mathrm{NO}_{2}[3,8-11$, 33]. The conversion rate may be affected by the aerosol surfaces and the surface water [10-12,14,19,33]. Therefore, the influence of $\mathrm{PM}_{2.5}$ and $R H$ were important to explore the heterogeneous reaction mechanism. Lab studies had shown that the reaction was first order in $\mathrm{NO}_{2}$ [10], and $\mathrm{HONO}$ / $\mathrm{NO}_{2}$ ratio was usually used to evaluate the extent from the heterogeneous reaction of $\mathrm{NO}_{2}[3,7,12,16,18]$. Nighttime $\mathrm{HONO} / \mathrm{NO}_{2}$ ratios in urban cities of China were from 0.03 to $0.15[7,12,14,20,23]$, higher ratios were obtained in Guangzhou with high relative humidity $[7,16]$. In this measurement, the variations of nocturnal $\mathrm{HONO} / \mathrm{NO}_{2}$ ratios in both urban and suburban areas were plotted in Figure 7. To avoid the uncertainties caused by the photolysis reaction in daytime, all the daytime data (from 7:00 LST to 18:00 LST) were ignored $[11,20]$. During the nighttime, the average $\mathrm{HONO} / \mathrm{NO}_{2}$ ratio was 0.044 and 0.110 , in urban and suburban areas, respectively. The higher ratios of $\mathrm{HONO} /$ $\mathrm{NO}_{2}$ in suburbans indicated higher conversion efficiency of $\mathrm{NO}_{2}$ heterogeneous reactions [11,33]. The heterogeneous formation of HONO could have occurred on various surfaces with different conversion rates, and the preferences to aerosol or ground surface were still in discussions [34]. However, compared to the urban surfaces of concrete, glass and foliage, the suburban surroundings provided much more surfaces for the heterogeneous reactions such as soils, lake, mineral dusts as well as numerous particles [34]. These factors may result in the high heterogeneous reaction efficiency in suburban areas. The heterogeneous reaction of $\mathrm{NO}_{2}$ could be affected by $\mathrm{NO}_{2}$ concentrations, relative humilities, the boundary layer heights, aerosol concentrations, the reactive surfaces and so on [25,33]. And then the effects of relative humidity and $\mathrm{PM}_{2.5}$ concentrations were studied.

Stutz et al. [11] pointed out that the absorbed water had influences on heterogeneous formation of HONO with independence on surfaces types. In other studies [7,11,12,14, $15,18,23,25,33]$, $\mathrm{HONO} / \mathrm{NO}_{2}$ ratios were $\sim 0.03$ on dry surfaces, increasing to $0.10-0.13$ on wet surfaces. However, $\mathrm{HONO} / \mathrm{NO}_{2}$ ratios on aqueous surfaces were uncertain [11,33]. In this measurement, it could be clearly identified in the suburban that (Figure 8), the $\mathrm{HONO} / \mathrm{NO}_{2}$ ratios increased from 0.02 to 0.15 with $R H$ from 0 to $85 \%$, and when the $R H$ was up to $85 \%, \mathrm{HONO} / \mathrm{NO}_{2}$ ratios decreased to 0.10 . The same phenomenon could also be seen in urban areas when $R H$ was higher than $90 \%$. However, the tendency was uncertain in the low $R H$ range due to the scattered points in the picture. It indicated that the absorbed water had complex effects on the $\mathrm{NO}_{2}$ heterogeneous formation of HONO. As a competition of HONO sources and sinks [9], the surface absorbed water could affect both processes of $\mathrm{NO}_{2}$ to $\mathrm{HONO}$ and HONO deposition. When the 

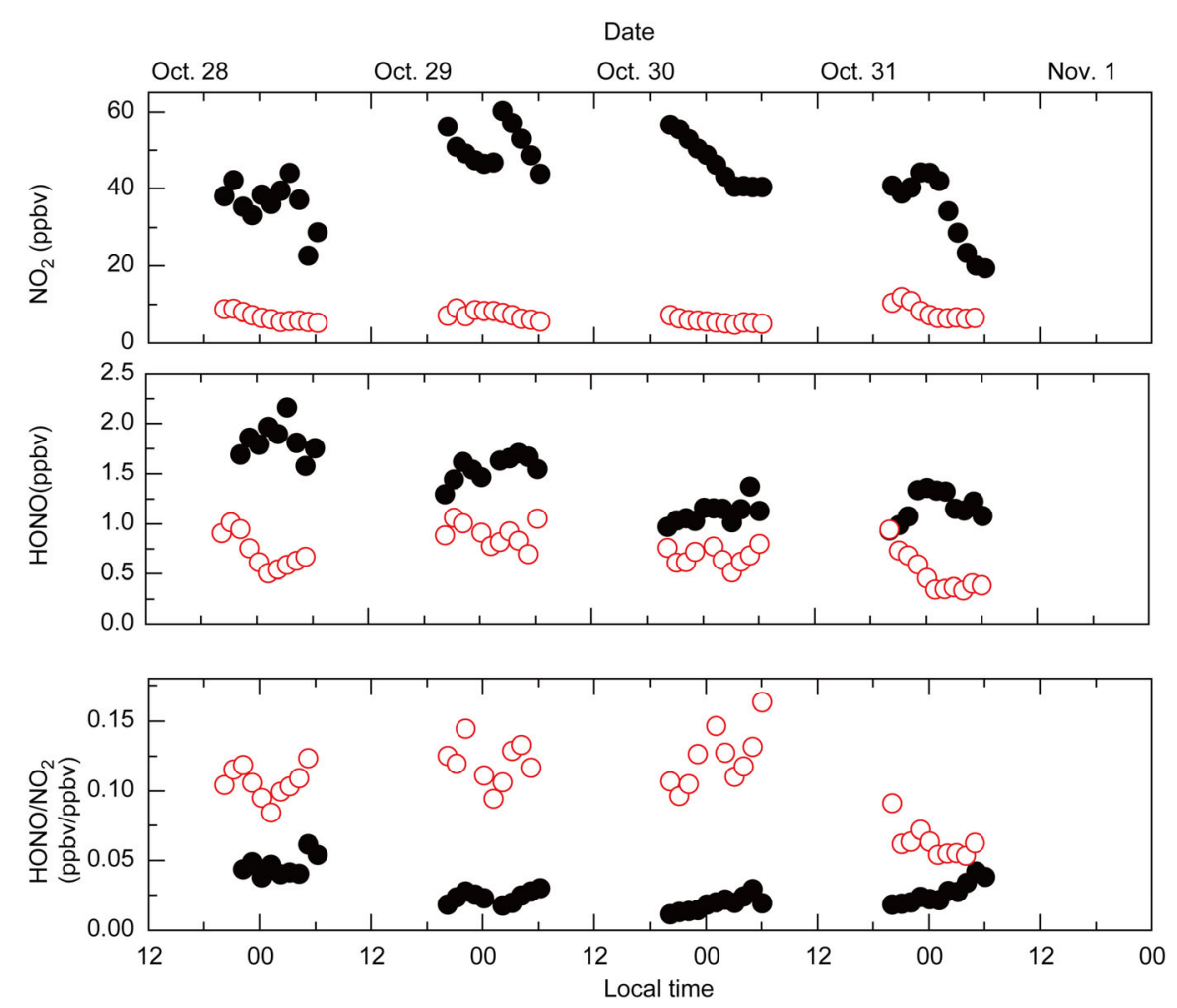

Figure 7 Time series of $\mathrm{HONO} / \mathrm{NO}_{2}$ ratios in the nighttime during the pollution period in urban area (black solid) and suburban (red hollow).
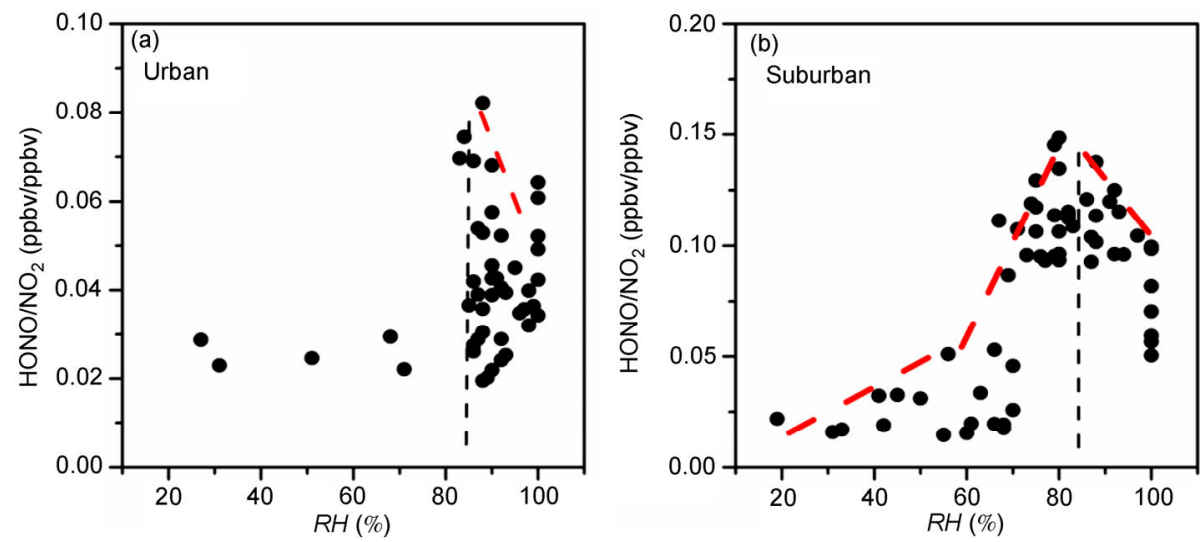

Figure 8 Correlations between HONO and $R H$ in urban site (a) and suburban site (b).

RH was from $20 \%$ to $80 \%$, the depositions of HONO would increase with $R H$. Moreover, the surface water coverage was increasing with $R H$. As the dependence on $R H$ of the heterogeneous conversion was stronger than the HONO deposition [11], the conversion efficiency would increase as a result. However, when the surface became saturated $(\mathrm{RH}>$ $85 \%)$, the excess water could be a limiting reagent for $\mathrm{NO}_{2}$ [33] and dissolution of HONO, which could result in a decrease in $\mathrm{HONO} / \mathrm{NO}_{2}$ ratios.

The particle mass concentration would also influence HONO heterogeneous formations $[14,16]$. To study this effect, correlations between $\mathrm{HONO} / \mathrm{NO}_{2}$ and $\mathrm{PM}_{2.5}$ were plot- ted (Figure 9). When the $\mathrm{PM}_{2.5}$ concentrations were lower than $100 \mu \mathrm{g} / \mathrm{m}^{3}$, the $\mathrm{HONO} / \mathrm{NO}_{2}$ ratios were increasing with the increase of $\mathrm{PM}_{2.5}$ concentrations both in urban and suburban areas. And the ratios declined after the $\mathrm{PM}_{2.5}$ concentrations were above $100 \mu \mathrm{g} / \mathrm{m}^{3}$. As seen in Figure 9, all the declining ratios were in high $R H$ region (higher than $80 \%$ ), in either urban or suburban area. So the decline of $\mathrm{HONO} / \mathrm{NO}_{2}$ ratios may be caused by the high content of absorbed water as it could be a limiting reagent for $\mathrm{NO}_{2}$ conversions. Therefore, although the particle matters could promote the HONO formation, in high $\mathrm{RH}$ ranges, the highly absorbed water would lead to a $\mathrm{HONO} / \mathrm{NO}_{2}$ decrease [11]. 

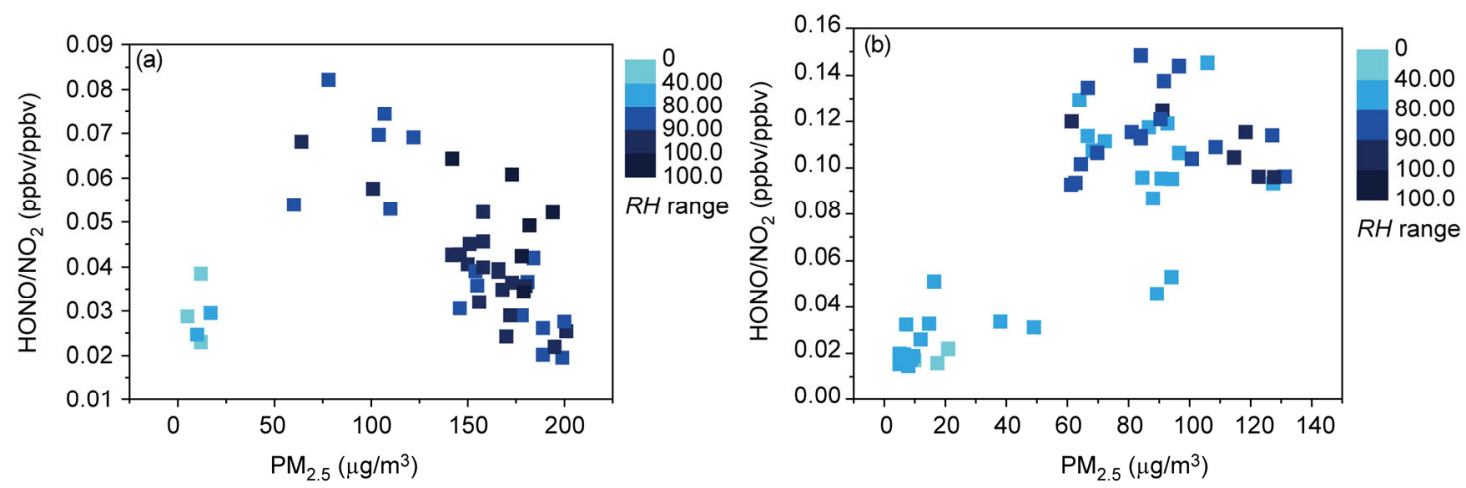

Figure 9 Correlations between $\mathrm{HONO}$ and $\mathrm{PM}_{2.5}$ concentrations in urban site (a) and suburban site (b).

\subsubsection{The nocturnal gas phase formation by $\mathrm{NO}$ and $\mathrm{OH}$}

The homogeneous reaction $\mathrm{NO}+\mathrm{OH} \rightarrow \mathrm{HONO}\left(K_{\mathrm{NO}+\mathrm{OH}}=\right.$ $9.8 \times 10^{-12} \mathrm{~cm}^{3} /\left(\right.$ molecules s) ) and $\mathrm{HONO}+\mathrm{OH} \rightarrow \mathrm{NO}_{2}+\mathrm{H}_{2} \mathrm{O}$ $\left(K_{\mathrm{HONO}+\mathrm{OH}}=6.0 \times 10^{-12} \mathrm{~cm}^{3} /(\right.$ molecules $\mathrm{s})$ ) would dominate the homogeneous production of HONO in nighttime [4]. Therefore, the net HONO homogeneous production could be calculated by $[3,4,7]$ :

$P_{\text {net }}=K_{\mathrm{NO}+\mathrm{OH}} \times[\mathrm{NO}] \times[\mathrm{OH}]-K_{\mathrm{HONO}+\mathrm{OH}} \times[\mathrm{HONO}] \times[\mathrm{OH}]$. where $P_{\text {net }}$ represented the net homogeneous production rate of the reation $\mathrm{NO}+\mathrm{OH} \rightarrow \mathrm{HONO}$ and $\mathrm{HONO}+\mathrm{OH} \rightarrow \mathrm{NO}_{2}+$ $\mathrm{H}_{2} \mathrm{O}[3,4,7]$; [] represented as the concentrations of gases. A nighttime $\mathrm{OH}$ concentrations of $1 \times 10^{6}$ molecules $/ \mathrm{cm}^{3}$ was assumed to represent the measured ones in both urban and suburban areas [18,35]. Since the reaction rates were similar, the $P_{\text {net }}$ was mainly decided by the concentrations of NO and HONO. For the urban area, the $P_{\text {net }}$ values were in proportion to NO concentrations, due to the high nocturnal NO concentrations. The average $P_{\text {net }}$ in urban area was much higher than in suburban area, which was $2.18 \mathrm{ppbv} / \mathrm{h}$ with the NO concentrations of $59.0 \mathrm{ppbv}$ and $0.137 \mathrm{ppbv} / \mathrm{h}$ with NO concentrations of 4.6 ppbv, in urban and suburban areas, respectively. Such a high $P_{\text {net }}$ value on urban areas would make the effect of homogeneous productions amazing. As shown in Figure 10, for the first night from 20:00 to 24:00, the mean $P_{\text {net }}$ values in urban area increased from 1.31 to $2.58 \mathrm{ppbv} / \mathrm{h}$ with HONO increasing from 1.37 to $2.01 \mathrm{ppbv}$. Therefore, by integrating $P_{\text {net }}$ in this $4 \mathrm{~h} \mathrm{[7],}$ the homogeneous reactions could provide at least $0.27 \mathrm{ppbv}$ accumulations of HONO, which was $42.2 \%$ of the measured increase of HONO (0.64 ppbv). In constrast to suburban areas, the low NO concentrations could only provide $P_{\text {net }}$ from 0.126 to $0.213 \mathrm{ppbv} / \mathrm{h}$ with an integrating area of 0.020 ppbv, which was $10.6 \%$ of HONO increasing $(0.187$ ppbv). It indicated that, when the concentrations of NO were extremly high, the net productions by homogeneous reactions could be dominant for the nighttime increase of HONO and its contribution would even exceed the formation
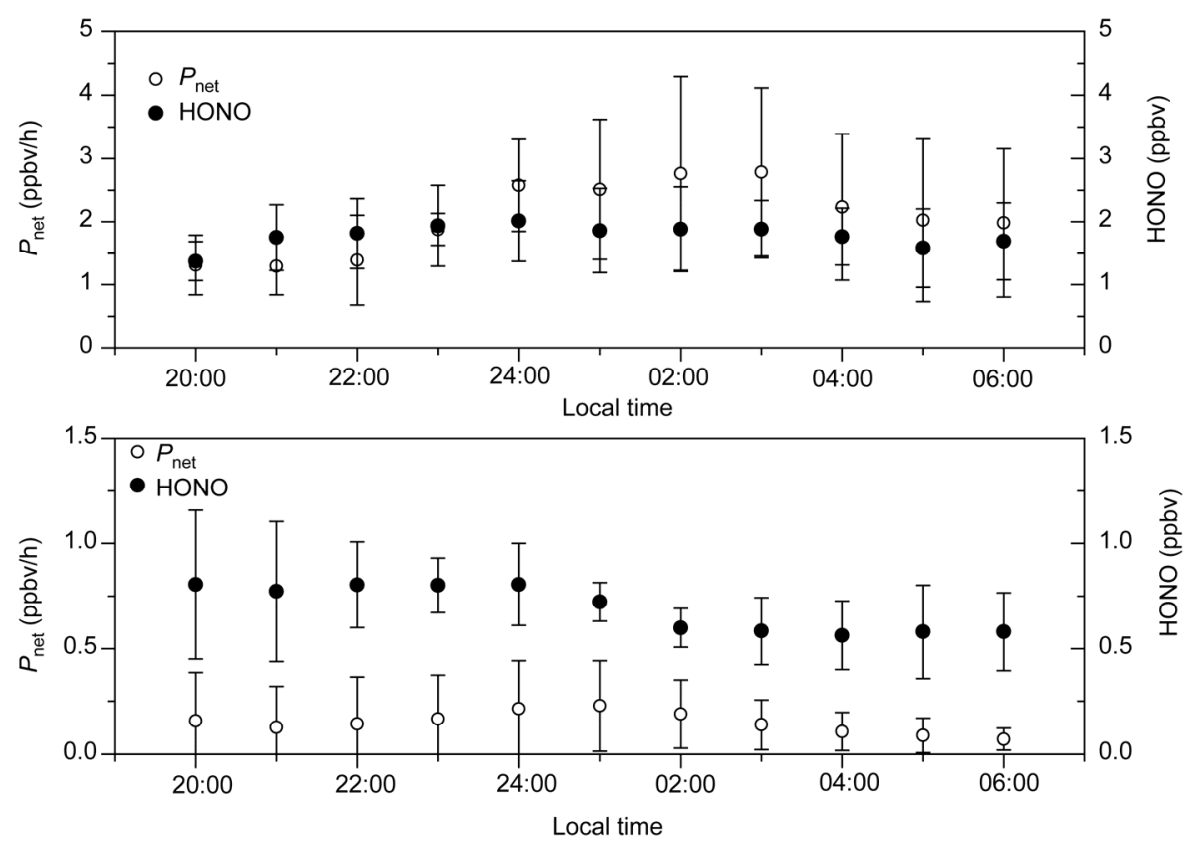

Figure 10 Average diurnal patterns of $P_{\text {net }}$ and HONO in the nighttime during the measurement period. 
by heterogeneous reactions [18].

To sum it up, the nocturnal HONO formation mechanisms in urban and suburban areas were different (Table 3). For the urban area, with the average contributions of $39.6 \%$ and $42.2 \%$, the direct emissions and the net homogeneous production would provide $81.8 \%$ of HONO formation. While in the suburban area, the on average contributions of direct emissions and the net homogeneous production was $8.5 \%$ and $10.6 \%$, respectively. Moreover, the mean HONO/ $\mathrm{NO}_{2}$ ratio in suburban area $(0.103)$ was 2.7 times higher than 0.038 in urban areas, which was in agreement with the remaining contributions of HONO formations. Therefore, for the urban and suburban areas, the differences in $\mathrm{NO}_{x}$ concentrations, NO concentrations, relative humidity and $\mathrm{PM}_{2.5}$ concentrations would lead to rather different HONO formations. The high $\mathrm{NO}_{x}$ concentrations would result in a high direct emissions of HONO, and the high NO concentrations would make the homogeneous reaction productions become significant. For the heterogeneous formations, particle concentrations and absorbed water on reactive surfaces would promote the HONO formation efficiency. In addition, higher $R H$ values would make HONO dissolved in water and result in a decline of $\mathrm{HONO} / \mathrm{NO}_{2}$ ratios.

\section{Conclusions}

A comparison study on HONO formation was performed in urban and suburban areas during a pollution period based on a continuous measurement from Oct. 28 to Nov. 3, 2014 in Beijing. During the measurement, both the sites in urban and suburban areas suffered a pollution process with mean $\mathrm{PM}_{2.5}$ concentrations of 130 and 85, respectively. The hourlyaveraged concentrations of $\mathrm{HONO}, \mathrm{CO}, \mathrm{SO}_{2}, \mathrm{O}_{3}, \mathrm{NO}, \mathrm{NO}_{2}$, and $\mathrm{NO}_{x}$ in the pollution period were ( $1.45 \mathrm{ppbv}, 0.61 \mathrm{ppmv}$, 8.7 ppbv, 4.3 ppbv, 44.4 ppbv, 37.4 ppbv, and 79.4 ppbv) much higher than concentrations in suburban $(0.72 \mathrm{ppbv}$, 1.00 ppmv, $1.2 \mathrm{ppbv}, 7.9 \mathrm{ppbv}, 3.7 \mathrm{ppbv}, 8.2 \mathrm{ppbv}$, and 11.9 ppbv). Correlations of $\mathrm{HONO}$ with $\mathrm{CO}, \mathrm{NO}_{x}$, and $\mathrm{SO}_{2}$ showed similar sources between $\mathrm{HONO}$ and $\mathrm{CO}, \mathrm{NO}_{x}$ in both areas, were mainly caused by direct emissions. The higher $\mathrm{HONO} / \mathrm{NO}_{x}$ ratios in urban areas also reflected higher contributions from direct emissions, while contributions of direct emissions were not significant in suburban areas. Moreover, the nocturnal $\mathrm{HONO} / \mathrm{NO}_{2}$ ratios, as a representa-

Table 3 Comparison of different pathways of HONO formation in urban and suburban areas during the nighttime ${ }^{\text {a) }}$

\begin{tabular}{cccccc}
\hline & $\begin{array}{c}\text { HONO } \\
(\mathrm{ppbv})\end{array}$ & $\begin{array}{c}\text { Direct } \\
\text { emission } \\
(\%)\end{array}$ & $\begin{array}{c}\text { Net } \\
\text { homogeneous } \\
\text { production } \\
(\%)\end{array}$ & $\begin{array}{c}\text { The rest } \\
\text { contributions } \\
(\%)\end{array}$ & $\begin{array}{c}\text { Heterogeneous } \\
\text { reaction } \\
\left(\mathrm{HONO} / \mathrm{NO}_{2}\right)\end{array}$ \\
\hline Urban & 1.78 & 39.6 & 42.2 & 18.2 & 0.038 \\
Suburban & 0.70 & 8.5 & 10.6 & 80.9 & 0.103 \\
\hline
\end{tabular}

a) All data were calculated by averaging the concentrations of Oct. 28-Oct. 31. tive of the heterogeneous reaction efficiencies, were 0.038 and 0.103 on average in urban and suburban areas, respectively. The higher $\mathrm{HONO} / \mathrm{NO}_{2}$ indicated a higher $\mathrm{NO}_{2}$ conversion efficiency in suburban areas. Moreover, the correlations of $\mathrm{HONO} / \mathrm{NO}_{2}$ vs. $R H$ and $\mathrm{HONO} / \mathrm{NO}_{2}$ vs. $\mathrm{PM}_{2.5}$ concentrations showed $\mathrm{RH}$ and particle concentrations could affect the $\mathrm{NO}_{2}$ conversion. When $R H$ was below $85 \%$, the $\mathrm{HONO} / \mathrm{NO}_{2}$ ratios increased with the $R H$ increasing, when $R H$ was higher than $85 \%$, the $\mathrm{HONO} / \mathrm{NO}_{2}$ would decline. Similarly, when $\mathrm{PM}_{2.5}$ concentrations were below 100 $\mu \mathrm{g} / \mathrm{m}^{3}$, the $\mathrm{HONO} / \mathrm{NO}_{2}$ ratios increased with the $\mathrm{PM}_{2.5}$ concentrations increasing. However, the decrease in HONO/NO $\mathrm{N}_{2}$ ratios when $\mathrm{PM}_{2.5}$ concentrations were higher than $100 \mu \mathrm{g} / \mathrm{m}^{3}$ was caused by the high $R H$, due to excess water limiting the conversion of $\mathrm{NO}_{2}$ and dissolution of HONO. At last, the net productions of homogeneous reactions of nighttime were compared. Due to extremely high concentrations of NO, the contributions of homogeneous reactions productions would be significant in HONO formations in urban areas.

This work was supported by the Strategic Priority Research Program (B) of the Chinese Academy of Sciences (XDB05010400), the Key Research Program of Chinese Academy of Sciences (KJZD-EW-TZ-G06-01), and the National Natural Science Foundation of China (41475114).

1 Lammel G, Cape JN. Nitrous acid and nitrite in the atmosphere. Chem Soc Rev, 1996, 25: 361-369

2 Harrison RM, Peak JD, Collins GM. Tropospheric cycle of nitrous acid. J Geophys Res, 1996, 101: 14429-14439

3 Kleffmann J, Kurtenbach R, Lorzer J, Wiesen P, Kalthoff N, Vogel B, Vogel H. Measured and simulated vertical profiles of nitrous acid. Part I: field measurements. Atmos Environ, 2003, 37: 2949-2955

4 Alicke B, Platt U, Stutz J. Impact of nitrous acid photolysis on the total hydroxyl radical budget during the limitation of oxidant production/pianura padana produzione di ozono study in Milan. $J$ Geophys Res, 2002, 107: LOP 9-1-LOP 9-17

5 Kurtenbach R, Becker KH, Gomes JAG, Kleffmann J, Lorzer JC, Spittler M, Wiesen P, Ackermann R, Geyer A, Platt U. Investigations of emissions and heterogeneous formation of HONO in a road traffic tunnel. Atmos Environ, 2001, 35: 3385-3394

6 Kirchstetter TW, Harley RA, Littlejohn D. Measurement of nitrous acid in motor vehicle exhaust. Environ Sci Technol, 1996, 30: 28432849

7 Li X, Brauers T, Haseler R, Bohn B, Fuchs H, Hofzumahaus A. Exploring the atmospheric chemistry of nitrous acid (HONO) at a rural site in southern China. Atmos Chem Phys, 2012, 12: 1497-1513

8 Grassian VH. Heterogeneous uptake and reaction of nitrogen oxides and volatile organic compounds on the surface of atmospheric particles including oxides, carbonates, soot and mineral dust: Implications for the chemical balance of the troposphere. Int Rev Phys Chem, 2001, 20: 467-548

9 Ammann M, Kalberer M, Jost DT, Tobler L, Rössler E, Piguet D, Gäggeler HW, Baltensperger U. Heterogeneous production of nitrous acid on soot in polluted air masses. Nature, 1998, 395: 157-160

10 Finlayson-Pitts BJ, Wingen LM, Sumner AL, Syomin D, Ramazan KA. The heterogeneous hydrolysis of $\mathrm{NO}_{2}$ in laboratory systems and in outdoor and indoor atmospheres: an integrated mechanism. Phys Chem Chem Phys, 2003, 5: 223-242

11 Stutz J, Alicke B, Ackermann R, Geyer A, Wang SH, White AB, Williams EJ, Spicer CW Jr, Fast JD. Relative humidity dependence 
of HONO chemistry in urban areas. J Geophys Res, 2004, 109: D03307

12 Acker K, Febo A, Trick S, Perrino C, Bruno P, Wiesen P, Moller D, Wieprecht W, Auel R, Giusto M, Geyer A, Platt U, Allegrini I. Nitrous acid in the urban area of Rome. Atmos Environ, 2006, 40: 3123-3133

13 Calvert JG, Yarwood G, Dunker AM. An evaluation of the mechanism of nitrous-acid formation in the urban atmosphere. Res Chem Intermediat, 1994, 20: 463-502

14 Hao N, Zhou B, Chen D, Chen LM. Observations of nitrous acid and its relative humidity dependence in Shanghai. J Environ Sci (China), 2006, 18: 910-915

15 Hendrick F, Muller JF, Clemer K, Wang P, De Mazière M, Fayt C, Gielen C, Hermans C, Ma JZ, Pinardi G, Stavrakou T, Vlemmix T, van Roozendael M. Four years of ground-based max-DOAS observations of $\mathrm{HONO}$ and $\mathrm{NO}_{2}$ in the Beijing area. Atmos Chem Phys, 2014, 14: 765-781

16 Qin M, Xie P, Su H, Gu JW, Peng FM, Li SW, Zeng LM, Liu JG, Liu WQ, Zhang YH. An observational study of the HONO-NO $\mathrm{NO}_{2}$ coupling at an urban site in Guangzhou city, south China. Atmos Environ, 2009, 43: 5731-5742

17 Qin M, Xie PH, Liu WQ, Li A, Dou K, Fang W, Liu JG, Zhnag WJ. Observation of atmospheric nitrous acid with DOAS in Beijing, China. J Environ Sci-China, 2006, 18: 69-75

18 Spataro F, Ianniello A, Esposito G, Allegrini I, Zhu T, Hu M. Occurrence of atmospheric nitrous acid in the urban area of Beijing (China). Sci Total Environ, 2013, 447: 210-224

19 Stutz J, Alicke B, Neftel A. Nitrous acid formation in the urban atmosphere: gradient measurements of $\mathrm{NO}_{2}$ and HONO over grass in Milan, Italy. J Geophys Res, 2002, 107: LOP 5

20 Su H, Cheng YF, Cheng P, Zhang YH, Dong SF, Zeng LM, Wang XS, Slanina J, Shao M, Wiedensohler A. Observation of nighttime nitrous acid (HONO) formation at a non-urban site during pridePRD2004 in China. Atmos Environ, 2008, 42: 6219-6232

21 Su H, Cheng YF, Shao M, Gao DF, Yu ZY, Zeng LM, Slanina J, Zhang YH, Wiedensohler A. Nitrous acid (HONO) and its daytime sources at a rural site during the 2004 pride-PRD experiment in China. J Geophys Res, 2008, doi: 10.1029/2007JD009060

22 Vogel B, Vogel H, Kleffmann J, Kurtenbach R. Measured and simulated vertical profiles of nitrous acid. Part II. Model simulations and indications for a photolytic source. Atmos Environ, 2003, 37: 29572966

23 Wang SS, Zhou R, Zhao H, Wang ZR, Chen LM, Zhou B. Long-term observation of atmospheric nitrous acid (HONO) and its implication to local $\mathrm{NO}_{2}$ levels in Shanghai, China. Atmos Environ, 2013, 77: 718-724

24 Wong KW, OH HJ, Lefer BL, Rappengluck B, Stütz J. Vertical profiles of nitrous acid in the nocturnal urban atmosphere of Houston, TX. Atmos Chem Phys, 2011, 11: 3595-3609

25 Yu Y, Galle B, Panday A, Hodson E, Prinn R, Wang S. Observations of high rates of $\mathrm{NO}_{2}-\mathrm{HONO}$ conversion in the nocturnal atmospheric boundary layer in Kathmandu, Nepal. Atmos Chem Phys, 2009, 9: 6401-6415

26 Wang YS, Yao L, Wang LL, Liu ZR, Ji DS, Tang GQ, Zhang JK, Sun Y, Hu B, Xin JY. Mechanism for the formation of the January 2013 heavy haze pollution episode over central and eastern China. Sci China Earth Sci, 2014, 57: 14-25

27 Sun YL, Jiang Q, Wang ZF, Fu PF, Li J, Yang T, Yin Y. Investigation of the sources and evolution processes of severe haze pollution in Beijing in January 2013. J Geophys Res, 2014, 119: 4380-4398

28 Quan J, Tie X, Zhang Q, Liu Q, Li X, Gao Y, Zhao D. Characteristics of heavy aerosol pollution during the 2012-2013 winter in Beijing, China. Atmos Environ, 2014: 83-89

29 Chen P, Zhang Q, Quan J, Gao Y, Huang MY. Temporal and spatial distribution of ozone concentration by aircraft sounding over Beijing (in Chinese). Chinese J Environ Sci, 2012: 4141-4150

30 Kleffmann J, Heland J, Kurtenbach R, Lorzer J, Wiesen P. A new instrument (LOPAP) for the detection of nitrous acid (HONO). Environ Sci Pollut R, 2002, 4: 48-54

31 Huang G, Zhou XL, Deng GH, Qiao HC, Civerolo K. Measurements of atmospheric nitrous acid and nitric acid. Atmos Environ, 2002, 36: 2225-2235

32 Heland J, Kleffmann J, Kurtenbach R, Wiesen P. A new instrument to measure gaseous nitrous acid (HONO) in the atmosphere. Environ Sci Technol, 2001, 35: 3207-3212

33 Wojtal P, Halla JD, McLaren R. Pseudo steady states of HONO measured in the nocturnal marine boundary layer: a conceptual model for HONO formation on aqueous surfaces. Atmos Chem Phys, 2011, 11: 3243-3261

34 Spataro F, Ianniello A. Sources of atmospheric nitrous acid: state of the science, current research needs, and future prospects. J Air Waste Manage, 2014, 64: 1232-1250

35 Lu KD, Rohrer F, Holland F, Fuchs H, Bohn B, Brauers T, Chang CC, Häseler R, Hu M, Kita K, Kondo Y, Li X, Lou SR, Nehr S, Shao M, Zeng LM, Wahner A, Zhang YH, Hofzumhaus A. Observation and modelling of $\mathrm{OH}$ and $\mathrm{HO}_{2}$ concentrations in the pearl river delta 2006: a missing oh source in a VOC rich atmosphere. Atmos Chem Phys, 2012, 12: 1541-1569 